\title{
Acute Toxicity Test of Amomum cardamomum (Kapulaga) Seed Extract on Hepatic Trasaminase Enzyme in Winstar Rats
}

\author{
Ratih D. Yudhani ${ }^{1}$, Riza N. Pesik ${ }^{2}$, Sarah Azzahro ${ }^{3}$, Adliah F. Anisa ${ }^{3}$, Rizka Hendriyani ${ }^{3}$ \\ ${ }^{1}$ Department of Pharmacology, Faculty of Medicine, Universitas Sebelas Maret, Surakarta, Indonesia, \\ ${ }^{2}$ Department of Pathology Anatomy, Faculty of Medicine, Universitas Sebelas Maret, Surakarta, \\ Indonesia, ${ }^{3}$ Faculty of Medicine, Universitas Sebelas Maret, Surakarta, Indonesia
}

\begin{abstract}
The herb frequently used as spices or remedies in the Indonesian community, with the seed as the most common part is kapulaga (Amomum cardamomum). According to earlier evidence, this possessed antibacterial, antifungal and several biological properties, reduced blood glucose and atherogenic parameter, and is developed as standardized herbal cures. However, the application of herbal medicine requires validating evidence of safety and effectiveness, including toxicity tests, particularly in clinical settings. The target organs in this comprised hepar, due to the role in several drug metabolism. This study aimed at discovering the safety profile of kapulaga seed extract based on the hepatic transaminase enzyme (SGOT and SGPT) level, by conducting an acute toxicity test in Winstar rats. Also, this was implemented with the OECD 420 Fixed-Dose Procedure, and the preliminary test employed $300 \mathrm{mg} / \mathrm{kg}$ BW dose followed by a maximum single quantity $(2000 \mathrm{mg} / \mathrm{kg} \mathrm{BW})$ of kapulaga. The main test was executed by a separation into control and treatment groups of 5 rats each. Therefore, a single dose of $2000 \mathrm{mg} / \mathrm{kg} \mathrm{BW} \mathrm{kapulaga}$ seed extract was administered to the treatment group, while the control group received standard pellets and water ad libitum. The blood from orbital vein was acquired on day 14, and SGOT and SGPT were subsequently assessed by an enzymatic-photometric method. Also, this data was analyzed using an independent sample t-test, and the mean of SGOT in both groups were $116.92 \pm 22.35$ and $98.02 \pm 16.38(\mathrm{p}=0.17)$, with $58.72 \pm 8.79$ and $47.64 \pm 7.30(\mathrm{p}=0.06)$ as SGPT respectively. Therefore, there was no statistical difference, and no acute toxicity signs were discovered. The maximum dose was not toxic and did not result in poisonous symptoms or alter hepatic transaminase enzyme (SGOT and SGPT) in rats.
\end{abstract}

Keywords: Amomum cardamomum, kapulaga, acute toxicity, SGOT, SGPT

\section{Uji Toksisitas Akut Ekstrak Biji Kapulaga (Amomum cardamomum) Berdasarkan Kadar Enzim Transaminase Hepar Tikus Winstar}

\begin{abstract}
Abstrak
Kapulaga (Amomum cardamomum), merupakan salah satu herbal Indonesia yang secara umum dimanfaatkan sebagai rempah-rempah maupun obat, terutama bagian biji. Beberapa bukti sebelumnya menunjukkan bahwa kapulaga memiliki berbagai aktivitas biologis seperti antibakteri, antijamur, dan sudah dibuktikan mampu menurunkan glukosa darah dan parameter arterogenik. Bukti tersebut mendukung pengembangan kapulaga sebagai obat herbal terstandar. Penggunaan obat herbal terutama di klinik harus didukung dengan adanya bukti keamanan maupun efektivitasnya termasuk uji toksisitas. Hepar merupakan salah satu target organ dari uji toksisitas karena perannya yang penting pada metabolisme sebagian besar obat. Penelitian ini bertujuan untuk menilai profil keamanan ekstrak biji kapulaga melalui uji toksisitas akut menggunakan tikus Winstar berdasarkan kadar enzim transaminase hepar (SGOT dan SGPT). Uji toksisitas akut berpedoman pada OECD 420 Fixed Dose Procedure. Uji pendahuluan menggunakan ekstrak biji kapulaga dosis $300 \mathrm{mg} / \mathrm{kg}$ BB dan diikuti dengan dosis tinggi $2000 \mathrm{mg} / \mathrm{kg} \mathrm{BB} \mathrm{yang}$ diberikan secara tunggal. Uji utama dilakukan dengan membagi tikus ke dalam kelompok kontrol dan perlakuan, masing-masing kelompok terdiri atas 5 tikus. Berdasarkan hasil uji pendahuluan, uji utama menggunakan dosis tunggal $2000 \mathrm{mg} / \mathrm{kg}$ BB untuk kelompok perlakuan, sedangkan kelompok kontrol hanya mendapatkan pelet dan air secukupnya. Pada hari ke-14, darah dari vena orbital diambil, lalu kadar SGOT dan SGPT diukur menggunakan metode enzymatic-photometric. Independent sample t-test digunakan untuk menilai data rata-rata kadar SGOT dan SGPT dari kedua kelompok. Rata-rata kadar SGOT pada kelompok kontrol dan perlakuan sebesar 116,92 $\pm 22,35$ dan 98,02 $\pm 16,38(\mathrm{p}=0,17)$, sedangkan rata-rata SGPT sebesar 58,72 $\pm 8,79$ dan 47,64 $\pm 7,30(\mathrm{p}=0,06)$. Perbedaan rata-rata SGOT dan SGPT pada kedua kelompok tersebut secara statistik tidak bermakna dan tidak ditemukan tanda toksisitas pada semua hewan coba. Ekstrak biji kapulaga dosis maksimal $2000 \mathrm{mg} / \mathrm{kg}$ BB tidak toksik pada hepar tikus karena tidak menimbulkan tanda toksisitas maupun mengubah enzim transaminase hati (SGOT dan SGPT).
\end{abstract}

Kata kunci: Amomum cardamomum, kapulaga, toksisitas akut, SGOT, SGPT

Correspondence: dr. Ratih D. Yudhani, M.Sc., Department of Pharmacology, Faculty of Medicine, Universitas Sebelas Maret, Surakarta, Central Java 57126, Indonesia, email: rdyudhani@gmail.com Submitted: $1^{\text {th }}$ February 2020, Accepted: $2^{\text {nd }}$ September 2020, Published: $9^{\text {th }}$ December 2020 


\section{Introduction}

The Food and Drug Supervisory Agency (2014) reports that more than 1000 species of plant in Indonesia can be utilized as herbal medicine because it has various biological activities that potential to be developed as a medicine to support the healthcare sector in Indonesia. ${ }^{1}$ The long history of herb and spices utilization in communities has been known. In recent years, there was an increasing concern of study in order to explore the biological properties of herbs for medicinal purposes. Moreover, herbs play an important role in health-promoting and improving the quality of life. ${ }^{2}$

One of the herbs that were often used by the community and familiar both as spice ingredients or as a drug is Amomum cardamomum (kapulaga). ${ }^{3}$ In many countries, the seeds of kapulaga are commonly used as a spice and widely used as a treatment to release the symptoms of dyspepsia, hiccupping, vomiting, and alcohol detoxification. ${ }^{4}$ Kapulaga is being the most extensively explored spices because it has been used as a traditional remedy for the treatment of mouth and throat infection, tuberculosis, renal and gallstones, etc. ${ }^{5}$ Research on the benefits of kapulaga or identification of its biological compound has been widely practiced. Kapulaga oil is effective as an antioxidant, due to its ability to increase glutathione level, which known as an antioxidant endogen. Furthermore, there was evidence this antioxidant activity is increased in a dose-dependent manner related to the content of kapulaga oil. ${ }^{6}$ Another study proved that the leaf extract of kapulaga has an effect on modulating the atherogenic index and blood sugar levels in rats diabetic model. ${ }^{7}$ In addition, dry fruits extract of Elletaria cardamomum Maton has antimicrobial activity against various grampositive and gram-negative bacteria such as Staphylococcus aureus and Escherichia coli. ${ }^{8}$
All those evidences support the development of Kapulaga as a standardized herbal medicine. Referring to the regulation of Indonesian Food and Drug Supervisory Agency No. HK.00.05.41.1384, standardized herbal medicines are medicinal natural ingredients which its efficacy and safety profile have been scientifically proven by preclinical testing and its compound has been standardized. ${ }^{9}$ One of the preclinical testing to assess the safety profile of a new compound is a single-dose acute toxicity test using animal model. ${ }^{10}$ Yudhani et al. (2019) have shown that kapulaga is not toxic to rat kidneys based on the acute toxicity test with urea and creatine parameters that are still in the normal range. ${ }^{11}$ However, the acute toxicity test of kapulaga focusing on the examination of rat liver function was still limited.

Phytochemicals screening of cardamom by Bhatti et al. (2010) revealed that cardamom contains total phenolic compounds and flavonoids of $0.317-1.66 \mathrm{~g} / 100 \mathrm{~g}$ and 11.33-14.63 g/100 g, respectively. ${ }^{12}$ The biotransformation of dietary phenol mainly via conjugation and oxidation process and hepar was one of the major sites for those reactions beside the small intestine. ${ }^{13}$ Moreover, hepar is the major organ for the detoxification of drugs and xenobiotics. On the other hand, collecting evidence showed that over a thousand agents, including medicines, chemical compounds, and some herbs related to drug-induced liver injury (DILI). It was estimated that DILI becomes the cause of $10 \%$ acute hepatitis in the clinical settings. The Food and Drug Administrations (FDA) reported that drug induce hepatotoxicity becomes the most common reason for nonreceiving or drug withdrawal from the market. ${ }^{14}$ The damage in hepatocyte will induce cell death and membrane leakage. It leads the release of serum glutamic oxaloacetic transaminase (SGOT) and serum glutamic pyruvic transaminase (SGPT) which were 
also known as aspartate aminotransferase (AST) and alanine aminotransferase (ALT) to the bloodstream. ${ }^{15-17}$ In line with that, aminotransferases (also called transaminase) and alkali phosphatase (AP) were known as the marker and sensitive indicator for hepatocellular injury. ${ }^{17}$ The aim of this study is to determine the safety profile of kapulaga seed extract through an acute toxicity test in Winstar rats based on the hepatic transaminase enzyme (SGOT and SGPT) level.

\section{Methods}

The extraction methods of $A$. cardamomum (kapulaga)

The A. cardamomum extraction using the maceration method was carried out in the Pharmacy Laboratory of Universitas Gadjah Mada, Yogyakarta. Dried A. cardamomum seeds were obtained from Kulon Progo, Yogyakarta. The dried seeds were ground using a mixer grinder to form a powder, then extracted by immersion the powder in $70 \%$ ethanol during 2 days periods. Filter the solution to separate the solid and liquid phases. Kept the liquid phase and a rotary evaporator was used to evaporate the solvent to get the dried-crude concentrated extracts that used in this study. The extract was stored in $-4{ }^{\circ} \mathrm{C}$ until used for analyses.

\section{The experimental rats}

The selection of experimental animals used in this study was conducted by purposive sampling, referring to the criteria in the OECD guideline 420 . The female Wistar rats (120-180 gram), not in pregnant condition, aged 8-12 weeks, with the variation of body weight not more than $\pm 20 \%$ from its average weight were used in this study. These rats were obtained from Laboratorium Penelitian dan Pengujian Terpadu (LPPT), Universitas Gadjah Mada, Yogyakarta, Indonesia.

One rat was used in the preliminary test and 10 rats were used in the main study which divided into two groups randomly, 5 rats in the control group and 5 rats in the treatment group. Rats were fed with standard pellet and were given water ad libitum. They were kept in plastic cages under a $12 \mathrm{hr}$ light/ dark cycle and room temperature $22-24{ }^{\circ} \mathrm{C}$. Rats were acclimatized to the environment 14 days prior to experimental use.

\section{Acute toxicity test}

This study was conducted under the ethical clearance from Health Research Ethical Commitee of Dr. Moewardi General Hospital/ School of Medicine Sebelas Maret University number 626/VI/HREC/2017.

This study was guided by the OECD 420 fixed-dose procedure which consists of a preliminary test and followed by the main test. The first dose of kapulaga seed extract in the preliminary test was $300 \mathrm{mg} / \mathrm{kg}$ body weight. Referring to OECD guideline, if there was no prior information related to the standard dose of the same chemical testing compound which estimated to provide toxicity's signs or evidence without causing toxic effects or mortality, the first dose of the preliminary test will be $300 \mathrm{mg} / \mathrm{kg}$ body weight. ${ }^{11,18}$

At this first dose, the rats can survive and showed no symptoms of toxicity, thus leading to an increasing dose to a high single dose ( $2000 \mathrm{mg} / \mathrm{kg}$ body weight) after 48 hours from the first treatment. ${ }^{18}$ The main test consists of two groups as mentioned before. Rats in the treatment group were given kapulaga 2000 $\mathrm{mg} / \mathrm{kg}$ body weight based on preliminary test, whilst rats in the control group were fed with standard pellet and water ad libitum. ${ }^{11,18}$

The examination of hepatic transaminase enzymes

On the $14^{\text {th }}$ day, rats were anaesthetized with ether. Blood samples (3 cc of each rat in both group) were collected from orbital venous plexus. Then, centrifuged the blood 
at $4000 \mathrm{rpm}$ for 10 minutes to get blood serum. The serum was stored at $-20{ }^{\circ} \mathrm{C}$ for biochemical analysis to determine the hepatic transaminase enzymes (SGOT and SGPT) that were assessed through enzymaticphotometric method using mix reagent for SGOT (DiaSys ASAT/GOT FS/IFCC mod. ref number 126019910 026, Holzheim, Germany) and SGPT (DiaSys ALAT/GPT FS/IFCC mod. ref number $1270199 \quad 10$ 026, Holzheim, Germany). The absorbance was read using spectrophotometer micro lab 300 in $340 \mathrm{~nm}$ wavelength. The factor of blank aquadest i.e. -1745 . The calculation formula to assess SGOT or SGPT level were described as follows: SGOT or SGPT level= $(\Delta$ Absorbance of $\mathrm{x}-1745) \mathrm{U} / \mathrm{l}$.

Statistical analysis

The data were analyzed using SPSS version 18. The level of transaminase enzyme was described as mean \pm standard deviation (SD). Those data normalities were previously assessed by Shapiro-Wilk test and followed by an independent sample t-test to analyze the statistical differences in SGOT and SGPT levels from both groups. A p-value of 0.05 or less was considered statistically significant.

\section{Results}

Preliminary test

A preliminary test was conducted to determine the dose that will be used in the main test. Table 1 showed there were no dead or toxicity signs of rat in the preliminary test using initial dose of cardamom at a single dose of $300 \mathrm{mg} /$ $\mathrm{kg}$ BW. Based on these results and referring to the OECD 420 guidelines, then this preliminary test was followed by increasing dose of cardamom to the maximum dose (2000 mg/kg BW). This maximum dose was given orally as single dose to the same rats, 48 hours after the first treatment.

Table 2 also documented that there were neither dead nor toxicity signs of rat which were given a maximum dose of cardamom (2000 mg/kg BW). Referring to the OECD 420 guidelines, if there were not any dead or toxicity signs, the treatment of main test used this maximum dose.

Main test

The main test consisted of 2 groups, i.e. the

Table 1 Evaluation of Toxicity Signs in Preliminary Study with $A$. cardamomum at Dose 300 mg/BW

\begin{tabular}{|c|c|c|c|c|c|c|c|c|c|c|}
\hline \multirow{2}{*}{ No. } & \multirow{2}{*}{ Toxicity Signs } & \multicolumn{9}{|c|}{ Time (Minutes) } \\
\hline & & 10 & 30 & 60 & 90 & 120 & 150 & 180 & 210 & 240 \\
\hline $1^{*}$ & Dead & - & - & - & - & - & - & - & - & - \\
\hline 2 & Piloerection & - & - & - & - & - & - & - & - & - \\
\hline 3 & Convulsion & - & - & - & - & - & - & - & - & - \\
\hline 4 & Tremor & - & - & - & - & - & - & - & - & - \\
\hline $5^{* *}$ & Pain reflex & $\mathrm{N}$ & $\mathrm{N}$ & $\mathrm{N}$ & $\mathrm{N}$ & $\mathrm{N}$ & $\mathrm{N}$ & $\mathrm{N}$ & $\mathrm{N}$ & $\mathrm{N}$ \\
\hline $6^{* *}$ & Pineal reflex & $\mathrm{N}$ & $\mathrm{N}$ & $\mathrm{N}$ & $\mathrm{N}$ & $\mathrm{N}$ & $\mathrm{N}$ & $\mathrm{N}$ & $\mathrm{N}$ & $\mathrm{N}$ \\
\hline 7 & Salivation & - & - & - & - & - & - & - & - & - \\
\hline 8 & Lacrimation & - & - & - & - & - & - & - & - & - \\
\hline 9 & Diarrhea & - & - & - & - & - & - & - & - & - \\
\hline 10 & Lethargy & - & - & - & - & - & - & - & - & - \\
\hline 11 & Hiperactivity & - & - & - & - & - & - & - & - & - \\
\hline 12 & Loss of consciousness & - & - & - & - & - & - & - & - & - \\
\hline
\end{tabular}


Table 2 Evaluation of Toxicity Signs in Preliminary Study with $A$. cardamomum at Dose $2000 \mathrm{mg} / \mathrm{BW}$

\begin{tabular}{clccccccccc}
\hline \multirow{2}{*}{ No. } & \multicolumn{1}{c}{ Toxicity Signs } & \multicolumn{10}{c}{ Time (Minutes) } \\
\cline { 2 - 10 } & & $\mathbf{1 0}$ & $\mathbf{3 0}$ & $\mathbf{6 0}$ & $\mathbf{9 0}$ & $\mathbf{1 2 0}$ & $\mathbf{1 5 0}$ & $\mathbf{1 8 0}$ & $\mathbf{2 1 0}$ & $\mathbf{2 4 0}$ \\
\hline $1^{*}$ & Dead & - & - & - & - & - & - & - & - & - \\
2 & Piloerection & - & - & - & - & - & - & - & - & - \\
3 & Convulsion & - & - & - & - & - & - & - & - & - \\
4 & Tremor & - & - & - & - & - & - & - & - & - \\
$5^{* *}$ & Pain reflex & $\mathrm{N}$ & $\mathrm{N}$ & $\mathrm{N}$ & $\mathrm{N}$ & $\mathrm{N}$ & $\mathrm{N}$ & $\mathrm{N}$ & $\mathrm{N}$ & $\mathrm{N}$ \\
$6^{* *}$ & Pineal reflex & $\mathrm{N}$ & $\mathrm{N}$ & $\mathrm{N}$ & $\mathrm{N}$ & $\mathrm{N}$ & $\mathrm{N}$ & $\mathrm{N}$ & $\mathrm{N}$ & $\mathrm{N}$ \\
7 & Salivation & - & - & - & - & - & - & - & - & - \\
8 & Lacrimation & - & - & - & - & - & - & - & - & - \\
9 & Diarrhea & - & - & - & - & - & - & - & - & - \\
10 & Lethargy & - & - & - & - & - & - & - & - & - \\
11 & Hiperactivity & - & - & - & - & - & - & - & - & - \\
12 & Loss of consciousness & - & - & - & - & - & - & - & - & - \\
\hline
\end{tabular}

(+): Toxicity sign was found; (-): No toxicity sign; *: If dead was found, give the time of dead in details; **: N (Normal reflex, $\mathrm{AbN}$ (Abnormal reflex)

control and treatment groups, each consisting of 5 rats. The evaluation of death and toxicity signs in rats on the first day and continued until the $14^{\text {th }}$ day, showed that there were no dead or any toxicity signs in all experimental animals both in the control and treatment groups. These results were represented by one of the experimental rat from the control group (Table 3) and treatment group (Table 4).

After the observation was completed on day 14 , the main test was continued with an examination of the liver biochemical parameters (SGOT and SGPT) from the blood serum of all rats in both the control and treatment groups. Results of the SGOT and SGPT tests (Table 5) showed that the high single dose of kapulaga seed extract (2000 $\mathrm{mg} / \mathrm{kg} \mathrm{BW}$ ) was not hepatotoxic from hepatic transaminase enzymes parameter. Kapulaga at this dose did not alter SGOT and SGPT

Table 3 Evaluation of Toxicity Signs of the Control Group in The Main Study

\begin{tabular}{|c|c|c|c|c|c|c|c|c|c|c|c|c|c|c|c|c|c|c|c|c|c|c|c|}
\hline \multirow{3}{*}{ No. } & \multirow{3}{*}{ Toxicity Signs } & \multicolumn{22}{|c|}{ Time } \\
\hline & & \multicolumn{9}{|c|}{ Day-1 (Minute) } & \multicolumn{13}{|c|}{ Day } \\
\hline & & 10 & 30 & 60 & 90 & 120 & 150 & 180 & 210 & 240 & 2 & 3 & 4 & 5 & 6 & 7 & 8 & 9 & 10 & 11 & 12 & 13 & 14 \\
\hline $1^{*}$ & Dead & - & - & - & - & - & - & - & - & - & - & - & - & - & - & - & - & - & - & - & - & - & - \\
\hline 2 & Piloerection & - & - & - & - & - & - & - & - & - & - & - & - & - & - & - & - & - & - & - & - & - & - \\
\hline 3 & Convulsion & - & - & - & - & - & - & - & - & - & - & - & - & - & - & - & - & - & - & - & - & - & - \\
\hline 4 & Tremor & - & - & - & - & - & - & - & - & - & - & - & - & - & - & - & - & - & - & - & - & - & - \\
\hline $5^{* *}$ & Pain reflex & $\mathrm{N}$ & $\mathrm{N}$ & $\mathrm{N}$ & $\mathrm{N}$ & $\mathrm{N}$ & $\mathrm{N}$ & $\mathrm{N}$ & $\mathrm{N}$ & $\mathrm{N}$ & $\mathrm{N}$ & $\mathrm{N}$ & $\mathrm{N}$ & $\mathrm{N}$ & $\mathrm{N}$ & $\mathrm{N}$ & $\mathrm{N}$ & $\mathrm{N}$ & $\mathrm{N}$ & $\mathrm{N}$ & $\mathrm{N}$ & $\mathrm{N}$ & $\mathrm{N}$ \\
\hline $6^{* *}$ & Pineal reflex & $\mathrm{N}$ & $\mathrm{N}$ & $\mathrm{N}$ & $\mathrm{N}$ & $\mathrm{N}$ & $\mathrm{N}$ & $\mathrm{N}$ & $\mathrm{N}$ & $\mathrm{N}$ & $\mathrm{N}$ & $\mathrm{N}$ & $\mathrm{N}$ & $\mathrm{N}$ & $\mathrm{N}$ & $\mathrm{N}$ & $\mathrm{N}$ & $\mathrm{N}$ & $\mathrm{N}$ & $\mathrm{N}$ & $\mathrm{N}$ & $\mathrm{N}$ & $\mathrm{N}$ \\
\hline 7 & Salivation & - & - & - & - & - & - & - & - & - & - & - & - & - & - & - & - & - & - & - & - & - & - \\
\hline 8 & Lacrimation & - & - & - & - & - & - & - & - & - & - & - & - & - & - & - & - & - & - & - & - & - & - \\
\hline 9 & Diarrhea & - & - & - & - & - & - & - & - & - & - & - & - & - & - & - & - & - & - & - & - & - & - \\
\hline 10 & Lethargy & - & - & - & - & - & - & - & - & - & - & - & - & - & - & - & - & - & - & - & - & - & - \\
\hline 11 & Hiperactivity & - & - & - & - & - & - & - & - & - & - & - & - & - & - & - & - & - & - & - & - & - & - \\
\hline 12 & $\begin{array}{l}\text { Loss of } \\
\text { consciousness }\end{array}$ & - & - & - & - & - & - & - & - & - & - & - & - & - & - & - & - & - & - & - & - & - & - \\
\hline
\end{tabular}

(+): Toxicity sign was found; (-): No toxicity sign; *: If dead was found, give the time of dead in details; **: N (Normal reflex, $\mathrm{AbN}$ (Abnormal reflex) 
Table 4 Evaluation of Toxicity Signs of the Treatment Group in The Main Study with A. cardamomum at Dose $2000 \mathrm{mg} / \mathrm{BW}$

\begin{tabular}{|c|c|c|c|c|c|c|c|c|c|c|c|c|c|c|c|c|c|c|c|c|c|c|c|}
\hline \multirow{3}{*}{ No. } & \multirow{3}{*}{ Toxicity Signs } & \multicolumn{22}{|c|}{ Time } \\
\hline & & \multicolumn{9}{|c|}{ Day-1 (Minute) } & \multicolumn{13}{|c|}{ Day } \\
\hline & & 10 & 30 & 60 & 90 & 120 & 150 & 180 & 210 & 240 & 2 & 3 & 4 & 5 & 6 & 7 & 8 & 9 & 10 & 11 & 12 & 13 & 14 \\
\hline $1^{*}$ & Dead & - & - & - & - & - & - & - & - & - & - & - & - & - & - & - & - & - & - & - & - & - & - \\
\hline 2 & Piloerection & - & - & - & - & - & - & - & - & - & - & - & - & - & - & - & - & - & - & - & - & - & - \\
\hline 3 & Convulsion & - & - & - & - & - & - & - & - & - & - & - & - & - & - & - & - & - & - & - & - & - & - \\
\hline 4 & Tremor & - & - & - & - & - & - & - & - & - & - & - & - & - & - & - & - & - & - & - & - & - & - \\
\hline $5^{* *}$ & Pain reflex & $\mathrm{N}$ & $\mathrm{N}$ & $\mathrm{N}$ & $\mathrm{N}$ & $\mathrm{N}$ & $\mathrm{N}$ & $\mathrm{N}$ & $\mathrm{N}$ & $\mathrm{N}$ & $\mathrm{N}$ & $\mathrm{N}$ & $\mathrm{N}$ & $\mathrm{N}$ & $\mathrm{N}$ & $\mathrm{N}$ & $\mathrm{N}$ & $\mathrm{N}$ & $\mathrm{N}$ & $\mathrm{N}$ & $\mathrm{N}$ & $\mathrm{N}$ & $\mathrm{N}$ \\
\hline $6^{* *}$ & Pineal reflex & $\mathrm{N}$ & $\mathrm{N}$ & $\mathrm{N}$ & $\mathrm{N}$ & $\mathrm{N}$ & $\mathrm{N}$ & $\mathrm{N}$ & $\mathrm{N}$ & $\mathrm{N}$ & $\mathrm{N}$ & $\mathrm{N}$ & $\mathrm{N}$ & $\mathrm{N}$ & $\mathrm{N}$ & $\mathrm{N}$ & $\mathrm{N}$ & $\mathrm{N}$ & $\mathrm{N}$ & $\mathrm{N}$ & $\mathrm{N}$ & $\mathrm{N}$ & $\mathrm{N}$ \\
\hline 7 & Salivation & - & - & - & - & - & - & - & - & - & - & - & - & - & - & - & - & - & - & - & - & - & - \\
\hline 8 & Lacrimation & - & - & - & - & - & - & - & - & - & - & - & - & - & - & - & - & - & - & - & - & - & - \\
\hline 9 & Diarrhea & - & - & - & - & - & - & - & - & - & - & - & - & - & - & - & - & - & - & - & - & - & - \\
\hline 10 & Lethargy & - & - & - & - & - & - & - & - & - & - & - & - & - & - & - & - & - & - & - & - & - & - \\
\hline 11 & Hiperactivity & - & - & - & - & - & - & - & - & - & - & - & - & - & - & - & - & - & - & - & - & - & - \\
\hline 12 & $\begin{array}{l}\text { Loss of } \\
\text { consciousness }\end{array}$ & - & - & - & - & - & - & - & - & - & - & - & - & - & - & - & - & - & - & - & - & - & - \\
\hline
\end{tabular}

(+): Toxicity sign was found; (-): No toxicity sign; *: If dead was found, give the time of dead in details; **: N (Normal reflex, $\mathrm{AbN}$ (Abnormal reflex)

in rats. Those enzymes level in both groups were not statistically different $(p>0.05)$ and there was not any mortality of rat either in the control or treatment groups.

\section{Discussion}

In the clinical settings, DILI was estimated $10 \%$ of all acute hepatitis cases and reached $50 \%$ from the whole of the acute liver failure with a $10 \%$ mortality rate. Many drugs and chemical agents were withdrawn at the postmarketing step due to the hepatotoxicity reaction, therefore the testing process of a new drug candidate should be conducted more rigorously. ${ }^{14}$ Previous studies proved that kapulaga has many biological activities and potential to be developed as standardized herbal medicine. There has been study on the safety profile of kapulaga focusing on the kidneys, ${ }^{11}$ meanwhile its toxicity test on the liver was not elucidated yet.

This present study was conducted to demonstrate the safety profile of kapulaga seed extract through an acute toxicity test, especially via the observation of hepatic transaminase enzymes. The toxicological study is important due to the evidence that the consumption of some herbs could have toxic effects. This study also needed to assess the target organ and to obtain preliminary data that can be used to determine the dose required for further toxicity test as a guide for deciding whether a new compound potential to be adopted for clinical use or not. ${ }^{18-20}$

Hepar is the largest and most vital

Table 5 Hepatic Biochemical Parameters in Rats which were Given High Single Dose of A. Cardamomum Seed Extract

\begin{tabular}{lccc}
\hline & \multicolumn{2}{c}{ A. cardamomum Seed Extract } & \\
\cline { 2 - 3 } $\begin{array}{l}\text { Hepatic Biochemical } \\
\text { Parameters }\end{array}$ & $\begin{array}{c}\text { Control Group } \\
(\mathbf{0} \mathbf{~ m g} / \mathbf{k g B W}) \\
(\mathbf{M e a n} \pm \mathbf{S D})\end{array}$ & $\begin{array}{c}\text { Treament Group } \\
\mathbf{( 2 0 0 0} \mathbf{~ m g} / \mathbf{k g B W}) \\
(\mathbf{M e a n} \pm \mathbf{S D})\end{array}$ & p-value \\
\hline SGOT(U/L) & $116.92 \pm 22.35$ & $98.02 \pm 16.38$ & \\
SGPT (U/L) & $58.72 \pm 8.79$ & $47.64 \pm 7.30$ & 0.17 \\
\hline Results are expressed as the mean $\pm \mathrm{SD}(\mathrm{n}=5)$ & & 0.06 \\
\hline
\end{tabular}


organ which plays an important role in the detoxification and elimination process of foreign substances. In addition, drug-induced toxicity of vital organs, including hepar, is frequently observed and the reason for withdrawal of an approved drug is toxicity mostly due to hepatotoxicity. ${ }^{21,22}$

Kapulaga was not toxic based on acute toxicity study referring to OECD 420 guideline, due to its maximum dose (2000 $\mathrm{mg} / \mathrm{kg} \mathrm{BW}$ ) did not cause any dead or toxicity signs in all rats. Moreover, the SGOT and SGPT levels in both groups are still in the normal range. Petterino et al. (2006) reported that the average levels of SGOT and SGPT enzymes in rats under normal conditions (without treatment) were in the minimum and maximum value ranges of 56.1-201.9 $\mathrm{U} / 1$ and 34.9-218.1 U/1, respectively. ${ }^{23}$ It has indicated that acute high single dose of $A$. cardamomum did not alter the liver function since the SGOT and SGPT level is still in the normal range.

SGOT (AST) is an enzyme found in many other tissues such as heart, skeletal and smooth muscle, kidney, and brain. Whilst, SGPT (ALT) is more specific to hepar, for it is found in the highest concentration in hepatocytes and low concentration in other tissues. After the severe damage of hepatocytes, it will lead to the increasing of the SGOT level, 10 to 20 times higher than normal, whereas the increase of SGPT level could be even higher, reaching up to 50 times greater than normal. Evaluating the characteristics and degree of elevation in those aminotransferases can help to determine the cause of liver injury. The elevation up to $300 \mathrm{IU} / 1$ are nonspecific, however the elevation level reaching more than $1000 \mathrm{IU} / 1$ is considered related to the massive hepatocellular injury, and one of the most causes are drug or toxin. ${ }^{17,24}$

This study showed that rats treated with acute high single dose of kapulaga did not alter the serum activities of SGOT and SGPT compared to control. Whilst, both of SGOT and SGPT level in the treatment group (98.02 \pm 16.38 and $47.64 \pm 7.30$ ) were lower than those in the control group (116.92 \pm 22.35 and 58.72 \pm 8.79 ), although there was no statistically difference. It might be due to the hepatoprotective activity of kapulaga. A study by Lim et al. (2016) clearly demonstrated that ethyl acetate fraction from $A$. cardamomum (EAAC) has hepatoprotective activity against CCl4-induced acute liver injury. The oxidative damage and lipid peroxidation are significantly reduced by EAAC treatment through its antioxidant properties. ${ }^{4}$ Aboubakr et al. (2016) also supported the hepatoprotective effect of cardamom. They revealed that aqueous extract of cardamom have protective effects on hepar rats against gentamicin-induced liver damaged. Cardamom significantly decreasing the level of biochemical parameters for liver injury such as AST, ALT, and bilirubin. It also improved the liver histological structure of rats model that was severely damaged by gentamicin induction. ${ }^{25}$ Those collected evidences supported the safety profile of kapulaga on the liver based on acute toxicity test which is documented in this study.

Protective effect of kapulaga is possibly mediated by biological activities of its compounds. Yashin et al. (2017) reported that the chemical compounds of spices, mainly the content of polyphenolic and other biologically active compounds, have the most role in the antioxidant activity of the spices. ${ }^{26}$ There was evidence that cardamom (kapulaga) extracts contain phenolic and flavonoid compounds. Moreover, the phytochemical analysis showed that the L-ethyl acetate fraction of Amomum cardamom (EAAC) was rich in polyphenols, flavonoids, and had significant antioxidant activity. ${ }^{4,27}$ Other study showed that phenolic and flavonoid compounds are secondary metabolites which act as antioxidants to exert many biological activities, such as antiinflammatory, antimicrobial, and antiviral 
effects. In addition, the most common activities of flavonoids were their potentiality to modulate the oxidative diseases, activating or inhibiting effects of various enzymes, and protecting from the risk of cardiovascular diseases by reducing the oxidation of lowdensity lipoproteins. ${ }^{28}$

The safety profile of kapulaga, especially on liver, supported the next study for the development of this herb as a standardized medicine in order to minimalize the incident of drug-induced liver injury, however, this study has limitation because the Alkaline Phosphatase (ALP) level was not measured. Ramaiah (2011) reported that besides the ALT and AST, ALP is also an important enzyme for evaluating the toxic effect of any drugs on the liver. ${ }^{29}$ Moreover, other liver function parameters such as bilirubin have not been assessed yet in this study.

\section{Conclusion}

The high single dose of kapulaga (Amomum cardamomum) seed extract (2000 mg/kgBW) was not toxic due to no any acute toxicity signs were showed and it did not alter the hepatic transaminase enzyme (SGOT and SGPT) in rat.

\section{Funding}

This research did not related to any funding agency in the public, commercial, or not-forprofit sectors.

\section{Conflict of Interest}

The authors declared no potential conflicts of interest with respect to the research, authorship, and/or publication of this article.

\section{References}

1. Badan Pengawas Obat dan Makanan
Republik Indonesia. Peraturan Kepala Badan Pengawas Obat dan Makanan Republik Indonesia nomor 13 tahun 2014. Pedoman Uji Klinik Obat Herbal. Jakarta: Badan Pengawas Obat dan Makanan Republik Indonesia: 2014.

2. Jiang TA. Health benefits of culinary herbs and spices. J AOAC Int. 2019;102(2): 395-411. doi: 10.5740/jaoacint.18-0418

3. Tjitrosoepomo G. Taksonomi tumbuhan obat-obatan, edisi ke-3. Yogyakarta: UGM Press; 2015.

4. Lim DW, Kim H, Park JY, Kim JE, Moon JY, Park SD, et al. Amomum cardamomum L. ethyl acetate fraction protects against carbon tetrachloride-induced liver injury via an antioxidant mechanism in rats. BMC Complement Altern Med Ther. 2016;16(2016):155. doi: 10.1186/s12906 -016-1121-1

5. Saeed A, Sultana B, Anwar F, Mushtaq M, Alkharfy KM, Gilani AH. Antioxidant and antimutagenic potential of seed and pods of green cardamom (Elletaria cardamom). Int J Pharmacol. 2014;10(8):461-9. doi: 10.3923/ijp.2014.461.469

6. Sharma S, Sharma J, Kaur G. Therapeutic uses of Elettaria cardomum. Int J Drug Formul Res. 2011;2(6):102-8. doi: 10.13 140/RG.2.2.12210.91848

7. Winarsi H, Sasongko ND, Purwanto A, Nuraeni I. Ekstrak daun kapulaga menurunkan indeks atherogenik dan kadar gula darah tikus diabetes induksi alloxan. Agritech. 2013;33(3):273-80. doi: 10.22146/agritech.9548

8. Kaushik P, Goyal P, Chauhan A, Chauhan G. In vitro evaluation of antibacterial potential of dry fruit extracts of Elettaria cardamomum Maton (Choti Elaichi). Iran J Pharm Res. 2010;9(3):287-92.

9. Badan Pengawas Obat dan Makanan Republik Indonesia. Peraturan Ketua Badan Pengawas Obat dan Makanan Republik Indonesia No. HK.00.05.41.1384 
Tahun 2005 Tentang Kriteria Dan Tata Laksana Pendaftaran Obat Tradisional, Obat Herbal Terstandar Dan Fitofarmaka. Jakarta: Badan Pengawas Obat dan Makanan Republik Indonesia; 2005.

10. Herbert CD. Basic overview of preclinical toxicology animal models, 2013 [Accessed on: 3 August 2018]. Available at: https://uab. edu/medicine/adda/images/131205\%20 Tox\%20Animal $\% 20$ Model s.pdf

11. Yudhani RD, Pesik RN, Azzahro S, Anisa AF, Hendriyani R. Renal function parameter on acute toxicity test of kapulaga (Amomum cardamom) seed extract in rat. IOP Conf Ser: Mater Sci Eng. 2019; 578:012053. doi: 10.1088/1757-899X/57 $8 / 1 / 012053$

12. Bhatti HN, Zafar F, Jamal MA. Evaluation of phenolic contents and antioxidant potential of methanolic extracts of green cardamom (Elettaria cardamomum). Asian J Chem. 2010;22(6):4787-94.

13. Hussain MB, Hasan S, Waheed M, Javed A, Farooq MA, Tahir A. Bioavailability and metabolic pathway of phenolic compounds. Intech Open. 2019;2019:118. doi: 10.5772/intechopen. 84745

14. Singh D, Cho WC, Upadhyay G. Druginduced liver toxicity and prevention by herbal antioxidants: An overview. Front Physiol. 2016;6:363. doi: 10.3389/ fphys.2015.00363

15. Komolkriengkrai M, Nopparat J, Vongvatcharanon U, Anupunpisit V, Khimmaktong W. Effect of glabridin on collagen deposition in liver and amelioration of hepatocyte destruction in diabetes rats. Exp Ther Med. 2019;18(2): 1164-74. doi: 10.3892/etm.2019.7664

16. Reza A, Rachmawati B. Perbedaan kadar SGOT dan SGPT antara subyek dengan dan tanpa diabetes mellitus. J Kedokt Diponegoro. 2017;6(2):158-66.

17. Woreta TA, Alqahtani SA. Evaluation of abnormal liver tests. Med Clin North Am.
2014;98(1):1-16. doi: 10.1016/j.mcna.20 13.09.005

18. Organization for Economic Co-operation and Development (OECD). OECD guidelines for testing of chemicals. Test no. 420: Acute oral toxicity fixed dose procedure. OECD 420;2001.

19. Arome D, Chinedu E. The importance of toxicity testing. J Pharm BioSci. 2013; 4:146-8.

20. Subhal D, Geetha N. Evaluation of acute toxicity of the methanolic extract of Tanacetum parthenium L. in albino wistar rats. J Sci Innov Res. 2017;6(3):113-5.

21. Paul S, Islam A, Tanvir EM, Ahmed $\mathrm{R}$, Das S, Rumpa NE, et al. Satkara (Citrus macroptera) fruit protects against acetaminophen-induced hepatorenal toxicity in rats. Evid-Based Compl Alt. 2016;2016:9470954. doi: 10.1155/2016/9 470954

22. Babai S, Auclert L, Le-Louet H. Safety data and withdrawal of hepatotoxic drugs. Therapie. 2017;S0040-5957(18)30036-2. doi: 10.1016/j.therap.2018.02.004

23. Petterino C, Argentino-Storino A. Clinical chemistry and haematology historical data in control Sprague-Dawley rats from pre-clinical toxicity studies. Exp Toxicol Pathol. 2006;57(3):213-9. doi: 10.1016/j. etp.2005.10.002

24. Eldin MS. Assessment of some biochemical tests in liver diseases smh. [Accessed on: 9 August 2018]. Available at: http://mans.edu.eg/files/pdf/conf/2012 19_Assessment_of_some_biochemical_ tests.pdf

25. Aboubakr M, Abdelazem AM. Hepatoprotective effect of aqueous extract of cardamom againts gentamicin induced hepatic damaged in rats. Int J Basic Appl Sci. 2016;5(1):1-4. doi: 10.14419/ijbas. v5i1.5435

26. Yashin A, Yashin Y, Xia X, Nemzer B. Antioxidant activity of spices and their 
impact on human health: A review. Antioxidants. 2017;6(3):70. doi: 10.3390/ antiox6030070

27. Amma KPAP, Rani MP, Sasidharan I, Nisha VNP. Chemical composition, flavonoid-phenolic contents and radical scavenging activity of four major varieties of cardamom. Int J Biol Med Res. 2010; 1(3):20-4.

28. Huyut Z, Beydemir S, Gülçin E. Antioxidant and antiradical properties of selected flavonoids and phenolic compounds. Biochem Res Int. 2017;2017:7616791. doi: $10.1155 / 2017 / 7616791$

29. Ramaiah SK. Preclinical safety assessment: Current gaps, challenges, and approaches in identifying translatable biomarkers of drug-induced liver injury. Clin Lab Med. 2011;31(1):161-72. doi: 10.1016/j.cll.201 0.10 .004 